\title{
Fundamental Frequency and Tone in Arabic Vowels and Consonants by Indonesian Speakers Aged 5 Years Old
}

\author{
Muhammad Ridwan ${ }^{1 *}$; Ulfah Nurul Amanah ${ }^{2}$ \\ ${ }^{1}$ Lecturer, Department of Arabic Literature, Universitas Sebelas Maret, Indonesia; \\ ${ }^{2}$ Graduate Student, Faculty of Cultural Sciences, Universitas Gadjah Mada, Indonesia \\ *Corresponding Author: muhammadridwan_fib@staff.uns.ac.id
}

\begin{abstract}
This study discusses the fundamental frequency and tone in Arabic vowels and consonants by Indonesian speakers aged 5 years old. The method of data collecting used an interview method by recording and writing techniques. It also employed one respondent who was 5 years old from the Javanese who resides in Surakarta city. The device used for recording was OPPO Joy 3 mobile phone, which is equipped with RecForge II program and microphone that can record sound clearly. An instrument that was used to know the fundamental frequency and tone was Praat 6.0 .26 version. The method of data analysis employed comparing method using the basic technique of elemental sorter technique, connecting technique, and differential technique. The result of the analysis showed that the fundamental frequency is correlated with the tone. If the fundamental frequency was high and likewise the tone. A vowel sound with the high fundamental frequency is sound [u], followed by [i], then [a]. The high and low frequency of vowel sounds affected the frequency of the consonant sound followed by the vowel. It was known that $52 \%$ of consonants with the high tone were accompanied by punctuation [d s $\left.^{5} \mathrm{mmah}\right], 40 \%$ were accompanied by punctuation [kasrah], and $8 \%$ were accompanied by punctuation [fathah]. The highest frequency sounding group was the apico-palatal sound. It happened since the apico-palatal sound was produced by vocal cord in a high vibration influencing the fundamental frequency and tone. Whereas, the group of consonant sounds with the lowest frequency was a pharyngeal sound as it had a low vibration on the vocal cord; hence, it only produced the low frequency sound.
\end{abstract}

Keywords: Phonetic; acoustic; vowels; consonants; Arabic language

\section{INTRODUCTION}

The sound of language is not only audible but can also be described in its form. The sound can be analyzed by a tone and its physical character can be analyzed by a fundamental frequency. The fundamental frequency and tone are parts of the supra segmental elements identifying the sound. Therefore, this study used the fundamental frequency because it has three linguistic functions (Irawan, 2012: 23). The three linguistic functions are: to inform the word that is considered important in the sentence; to identify syntactic/ prosodic structure; and to qualify the word's speech (statement/ question).

The tone is selected because it can identify the speaker's origin language. In addition, tone variations can be used to express meaning differences in the word level and mean differences in sentence phrases (Muslich, 2012: 62).

Arabic sounds consist of vowel and consonant. Both sounds are very important as a basic sound in Arabic. The vowel and consonant sounds function to complement each other. Arabic is the language used by most speakers, both native speakers and non-native speakers. One of the non-native Arabic speakers is an Indonesian 5-year-old child.

The 5-year-old speaker has a perfect articulation tool, so he can produce Arabic vowel and consonant 
sounds fluently. In addition, children who are in the age ranged from 0-8 years old experienced a golden age on brain growth (Syaodih, 2002: 26). This golden age allows children to distinguish some consonants that have similar sound. The similar consonant sounds in Arabic are understandable to the child, but the child has not been able to utter some other consonants. A speech inaccuracy becomes a distinctive feature for the speaker. The characteristics of speech can also be recognized from acoustic markers. There are differences in acoustic characteristics of adults and children. The children are generally still affected by the mother's language intonation that is rather excessive and the speech rate that is rather slow (Pine, 1994: 15, in Dardjowidjojo, 2016: 242). The intonation of adult speech is not too excessive and the rate of speech is not slow. Some languages have different characteristics when spoken by different people. It happens because each individual has a different physical channel size (Irawan, 2017: 101).

Several studies have been conducted on prosodic features, Arabic vowel, and consonant sound, for instance, Almisreb, et al (2015) who examined the short and long vowels on the consonants. The result showed that there was an overlap between the duration of short vowels and long vowels in Arabic at the speech of a Malaysian speaker. Alqattan (2015) examined children phonological acquisition in Kuwait. The result of the study showed that the children phonological acquisition is presented in percent form. Subali (2015) examined the fundamental frequency and frequency of the formant for the pronunciation of Arabic alphabet by the DTW method. The result of this research showed that the correlation distance between novice speaker and expert speaker with GUI application. Kadir and Sudirman (2011) examined the frequency of the phonetic sounds of Arabic consonants. The results of this study indicate that there are 7 letters of Arabic alphabet which Malaysian children find it difficult to pronounce, they are: [q], [்̇, $[\mathrm{x}],[\gamma],[\hbar],[\mathrm{G}]$ and $[\mathrm{h}]$. The following table describes the previous phonetic research as well as the research positions discussed in this journal.

Based on this background, this research attempts

Table 1: Comparison of previous studies with this research

\begin{tabular}{|c|c|c|c|}
\hline Researcher & Research result & Object of Research & Respondents \\
\hline $\begin{array}{l}\text { Almisreb,et al } \\
(2015)\end{array}$ & $\begin{array}{l}\text { The results show there is an overlap between } \\
\text { short vocal duration and long vowel in Arabic } \\
\text { spoken by Malaysian speakers }\end{array}$ & $\begin{array}{l}\text { The duration of short and long } \\
\text { vowels on consonants }\end{array}$ & $\begin{array}{l}8 \text { Malaysian } \\
\text { speakers }\end{array}$ \\
\hline Alqattan (2015) & $\begin{array}{l}\text { The results of these studies show the } \\
\text { acquisition of child phonology and are } \\
\text { presented in percentage }\end{array}$ & Phonological acquisition & $\begin{array}{l}\text { Kuwait Speakers } \\
\text { aged } 1,4-3,7 \\
\text { years old }\end{array}$ \\
\hline $\begin{array}{l}\text { Jamil,et al } \\
(2015)\end{array}$ & $\begin{array}{l}\text { The results show that the frequency of } \\
\text { duration in Indonesian speakers is smaller than } \\
\text { the native speakers, but the duration period in } \\
\text { Indonesian speakers is longer than the native } \\
\text { speakers. }\end{array}$ & $\begin{array}{l}\text { The duration of interrogative, } \\
\text { imperative, and declarative } \\
\text { sentences in Arabic }\end{array}$ & $\begin{array}{l}4 \text { Indonesian } \\
\text { speakers and } 1 \\
\text { Arabic speaker }\end{array}$ \\
\hline Subali (2015) & $\begin{array}{l}\text { The result of this research is showed the } \\
\text { distance of correlation between novice speaker } \\
\text { and expert speaker with GUI application }\end{array}$ & $\begin{array}{l}\text { The fundamental frequency } \\
\text { and the frequency of the } \\
\text { forman for the pronunciation } \\
\text { of makhraj by the DTW } \\
\text { method }\end{array}$ & $\begin{array}{l}1 \text { expert } \\
\text { pronounced the } \\
\text { hijaiyyah letter, } \\
\text { and } 1 \text { beginner }\end{array}$ \\
\hline $\begin{array}{l}\text { Kadir and } \\
\text { Sudirman (2011) }\end{array}$ & $\begin{array}{l}\text { The results of this research indicate that } \\
\text { there are } 7 \text { letters of Hijaiyah that Malaysian } \\
\text { children find it difficult to pronounce, namely } \\
{[\mathrm{q}],[\dot{\mathrm{z}}],[\mathrm{x}],[\gamma],[\hbar],[\mathrm{G}] \text { and }[\mathrm{h}] \text {. }}\end{array}$ & $\begin{array}{l}\text { The frequency of the sound of } \\
\text { Arabic consonants }\end{array}$ & $\begin{array}{l}\text { Malaysian 7- to } \\
11 \text {-year-old } \\
\text { speakers }\end{array}$ \\
\hline This Research & $\begin{array}{l}\text { The result shows that the vowel sounds } \\
\text { expressed by non-native speakers are higher } \\
\text { than native speakers. As for consonant sound, } \\
\text { the frequency of non-native speakers' speech } \\
\text { is lower than the native speaker. }\end{array}$ & $\begin{array}{l}\text { The fundamental frequency } \\
\text { and tone of Arabic vowels and } \\
\text { consonants }\end{array}$ & $\begin{array}{l}\text { Indonesian } \\
\text { 5-year-old } \\
\text { speakers }\end{array}$ \\
\hline
\end{tabular}


to answer: How is the fundamental frequency of Arabic vowels and consonants pronounced by Indonesian 5-year-old children?; How is the tone of Arabic vowels and consonants pronounced by Indonesian 5-year-old children? The benefit of this research is to know the fundamental frequency and tone of vowels and consonants that are pronounced by Indonesian children speakers who attain the age of 5 years old. This research used several theories on the science of phonology as the theoretical basis.

\section{THEORETICAL BASIS}

Phonology is a field in linguistics that investigates the sounds of language according to its function (Kridalaksana, 2009: 3). Chaer (2007: 102) said phonology is a science that studied, analyzed, and talked about sounds of language. The phonology of this study examined the sound of language regardless of the change in meaning and this study was included in the phonetic study.

According to the sequence of the process of the sound of language, there are three types of phonetics: articulatory phonetics, acoustic phonetics, and auditory phonetics (Sangidu, 1991: 10-11). Articulatory phonetics is also called as organic phonetics or physiological phonetics. Articulatory phonetics is a branch of phonetics that investigates sounds based on speech tool in articulation. Acoustic phonetics is a branch of phonetics that investigates the physical characteristics of the sounds of language. Auditory phonetics investigates sounds as hearing language perceptions (Kridalaksana, 2009: 63).

Phonology has two elements of sound both encompassing segmental elements and supra-segmental elements. Segmental sounds in Arabic are grouped into bilabial, labiodental, alveolar, dental, apico-alveolar, apico-palatal, uvular, and pharyngeal (Anis, 1999: 43-76). This grouping is based on the proximity of the articulation tool. The supra-segmental sound, according to Muslich (2012: 61), is a high-low sound (tone), loud sounds (pressure), short-sound (tempo), and silence (pause).

Acoustics phonetics is the science that investigates the physical characteristics of the sounds of language. Acoustic phonetics focuses on the acoustic characteristics of sound waves of language, so that the acoustic phonetic sphere is outside the physical participants of the speech. The sound form of language in acoustic phonetic studies can be visualized into spectrum, waveform or spectrograph. In the waveform or spectrogram, the sound energy of the speech is indicated by black blobs. One study of acoustic phonetics is the fundamental frequency and tone.
The fundamental frequency is one of the acoustic components in the speech production which is often referred to as pitch. The fundamental frequency is usually denoted by $f_{o}$ and can only be identified with complex waves. The fundamental frequency measurement can be expressed by the size of Hertz $(\mathrm{Hz})$, Hertz is the unit of frequency (Irawan, 2012: 28). There are different lengths and muscles of the vocal cords in men, women, and children that cause the difference in the average fundamental frequency range. For example, Clark and Yallop (in Irawan, 2012: 24) illustrate that the average fundamental frequency range of English speakers is 80$200 \mathrm{~Hz}$ (male), 150-300 Hz (female), and 200-500 Hz (children).

Tone is related to the height and low of a sound. When a segmental sound is pronounced with a high vibration frequency, it will be accompanied by a high tone. Conversely, if sound is pronounced with a low vibration frequency, it will be accompanied by a low tone (Sangidu, 1991: 64). An utterance to the sound of the language has a basic tone (BT), final tone (FT), lowest tone (LT), and highest tone (HT). The fundamental frequency and tone in this study were calculated using a software called Praat version 6.0.26.

Praat in German means 'to speak' (Irawan, 2017: 153). Praat is a program used for phonetic analysis and sound manipulation. This program is created by Paul Boersma and David Weenink. Both scientists came from the Institute of Phonetic Sciences, the University of Amsterdam (Welby and Ito, 2002: 1). Praat program is very flexible for analyzing human speech. Praat program describes some topics, such as searching manually, creating sound objects, processing signals, waveform labels, general analysis (wave, intensity, sonogram, pitch, duration), spectrographic analysis, intensity analysis, using long voice files (Hartanti, et al, 2016: 3).

\section{RESEARCH METHODS}

The method of data collecting used a prattle method with basic provoke technique. Data were collected using recording the speech of speakers. The data were taken from a Javanese 5-year-old boy from Indonesia. The device used for recording was OPPO Joy 3 mobile phone which is equipped with RecForge II program and microphone that can capture sound clearly.

The method of analysis used comparing method in which the basic technique used the elemental sorter technique and connecting and differential technique (Sudaryanto, 2015: 15). The first data analysis process consisted of calculating the fundamental frequency of 
Arabic vowels and consonants by Indonesian children. The second stage was to find out the tone of Arabic vowels and consonants using Praat program version 6.0.26. Consonant sounds in tone analysis are grouped according to bilabial, labiodental, alveolar, dental, apico-alveolar, apico-palatal, uvular, and pharyngeal (Anis, 1999: 43-76). This grouping is based on the proximity of the articulation tool. Data were described using tables and diagrams.

\section{ANALYSIS AND DISCUSSION}

\section{Measurement of Fundamental Frequencies}

The fundamental frequency measurement can be done using the following formula:

Table 2. The formula calculates the fundamental frequency

$\frac{1000 \times \text { number of vertical lines }}{\text { Time }}$

An example of the vowel sound [a] pronounced by Indonesian children speakers has a fundamental frequency of $250 \mathrm{~Hz}$. The fundamental frequency was obtained from the calculation as follows:

Table 3. The formula calculates the fundamental frequency of the vowel sound [a]

$\frac{1000 \times 14.5}{58 \text { milli seconds }}=250$

The calculation is not much different from the results obtained on Praat automatically. The fundamental frequency of the vowel and consonant sounds can be viewed automatically through the Praat software by blocking the sound portion of the spectrum to know its frequency. The table below shows the fundamental frequency of Arabic vowel sounds pronounced by Indonesian children aged 5 years old.

Table 4. Fundamental frequency of Arabic vowels

\begin{tabular}{|l|c|c|c|}
\hline Frequency (Hz) & drammah $_{\text {fathah }}$ & kasrah \\
\hline $\mathrm{f}_{\mathrm{o}}$ & 286.5 & 250.1 & 281.4 \\
\hline
\end{tabular}

The highest frequency of the vowels of children is d'ammah with a frequency of $286.5 \mathrm{~Hz}$, followed by frequency of kasrah with a frequency of $281.4 \mathrm{~Hz}$. Vowels with the lowest frequency is fathah with a frequency of $250.1 \mathrm{~Hz}$. The table below shows the fundamental frequency of Arabic consonant sounds pronounced by Indonesian 5-year-old children.

Table 5. Fundamental frequency of Arabic consonant

\begin{tabular}{|c|c|c|c|c|}
\hline \multirow{2}{*}{\multicolumn{2}{|c|}{ Consonant }} & \multicolumn{3}{|c|}{ Frequency $(\mathrm{Hz})$} \\
\hline & & \multirow{2}{*}{$\frac{d_{n}^{\text {s}} a m m a h}{281.5}$} & \multirow{2}{*}{$\begin{array}{c}\text { fathah } \\
261.7\end{array}$} & \multirow{2}{*}{$\begin{array}{r}\text { kasrah } \\
271.6\end{array}$} \\
\hline \multirow{2}{*}{ Bilabial } & ب/b & & & \\
\hline & م/m & 274.2 & 272.1 & 287.4 \\
\hline Labiodental & اف /f & 283.1 & 269.8 & 290.4 \\
\hline \multirow{3}{*}{ Alveolar } & د & 261.8 & 267.9 & 282.1 \\
\hline & $ث / \theta$ & 269.4 & 346.5 & 281.6 \\
\hline & b/z & 256.5 & 286.4 & 288.5 \\
\hline \multirow{7}{*}{ Dental } & $\mathrm{s} / \mathrm{d}$ & 273.1 & 257.2 & 284.3 \\
\hline & ل d / ע / & 297.4 & 251.5 & 261.1 \\
\hline & $ت / \mathrm{t}$ & 333.3 & 303.2 & 273.4 \\
\hline & $b / t^{\varsigma}$ & 293.3 & 291.7 & 273.5 \\
\hline & / / & 283.0 & 262.9 & 281.3 \\
\hline & $j / z$ & 286.9 & 258.4 & 282.3 \\
\hline & ل ص / s & 300.7 & 227.6 & 272.3 \\
\hline \multirow{3}{*}{$\begin{array}{l}\text { Apico- } \\
\text { alveolar }\end{array}$} & J/1 & 311.4 & 265.9 & 292.9 \\
\hline & $J / r$ & 272.6 & 271.4 & 286.9 \\
\hline & ن/n & 280.8 & 235.9 & 286.7 \\
\hline \multirow{2}{*}{ Apico-palatal } & ת א ش & 345.9 & 250.5 & 266.7 \\
\hline & ا & 292.8 & 272.8 & 265.9 \\
\hline \multirow{2}{*}{ Uvular } & ك/k & 292.1 & 268.2 & 299.8 \\
\hline & و/q & 264.3 & 247.9 & 287.7 \\
\hline \multirow{5}{*}{ Pharyngeal } & $\dot{\varepsilon} / \gamma$ & 181.4 & 258.7 & 276.5 \\
\hline & $\dot{\tau} / \mathrm{x}$ & 273.8 & 260.7 & 272.8 \\
\hline & $\varepsilon / \varsigma$ & 263.0 & 297.4 & 258.8 \\
\hline & $\tau / \hbar$ & 315.9 & 271.4 & 305.9 \\
\hline &.$/ \mathrm{h}$ & 277.7 & 258.7 & 267.2 \\
\hline
\end{tabular}

The table above shows that the Arabic consonant has different frequencies between one another. In the bilabial area, the highest frequency is consonant [m], while the lowest is consonant [b]. In the labio-dental area, the highest frecuency is consonant [f]. In the alveolar area, the highest frequency is $[\theta]$ and the lowest frequency is $[ð]$. The plosive area shows that the highest frequency is [t] and the lowest is [d]. The apico-alveolar area shows that the highest frequency is consonant [1] dan the lowest is [n]. In the fricative area, the higest frequency is [z] and the lowest consonant is [s] . In the apico-palatal area, the highest frequency is $[J]$ and the lowest is [j]. In the 
dorsum area, the highest frequency is [k] and the lowest is [q]. In the pharyngeal area, the highest frequency is [ $\hbar$ ] and the lowest is $[\gamma]$

\section{Measurement of Tone}

The graph below shows the frequency of the basic tone (BT), the final tone (FT), the highest tone (HT), and the lowest tone (LT) on the vowels [a], [i], and [u] uttered by a Indonesian 5 -year-old speaker.

Figure 1. The tone of Arabic vowels by a 5-year-old Indonesian speaker

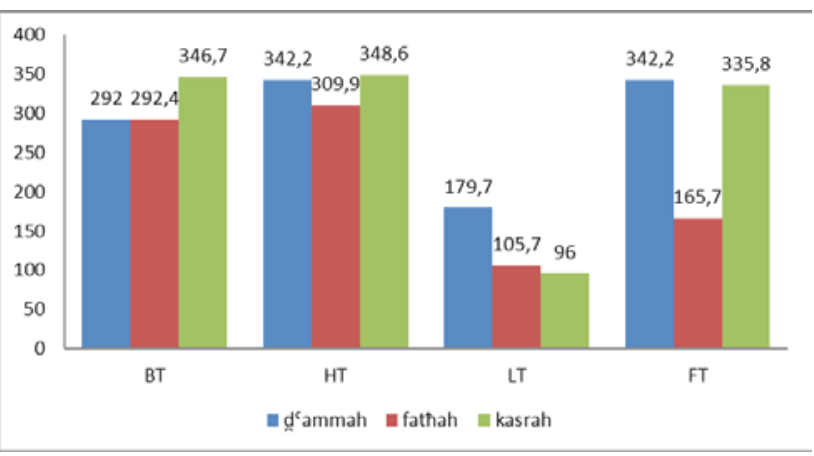

The highest basic tones of Arabic vowel is [kasrah], and the lowest is [d'ammah]. The highest final tone of Arabic vowel is [d d $\left.^{\prime} a m m a h\right]$ and the lowest is [fathah]. Based on average frequency of tone, the highest tone is [kasrah], the middle tone is [d'ammah], and the lowest tone is [fathah]. The graph below shows the frequency of the basic tone, the final tone, the highest tone, and the lowest tone of the consonant with [d $\left.d_{\text {s }} a m m a h\right]$ vowel. Therefore, based on the average high frequency, it can be seen that the highest vowel frequency is [d ammah] and the lowest is [fathah]. This happens because the sound [ $\left.d_{n}^{\text {s }} a m m a h\right]$ has a high wave vibration when it was articulated. The table below shows the frequency of the basic tone (BT), the final tone (FT), the highest tone (HT), and the lowest tone (LT) of Arabic consonant by Indonesian children.

The table 6 shows the frequency of tone of bilabial consonant pronounced by a 5 -year-old Indonesian speaker. Data were obtained from calculations automatically with Praat program. In Arabic sounds, punctuation has a very strong infuence that can affect the high and low tones. Consonant $[\mathrm{b}]$ has a high frequency when punctuation [d d $^{\top}$ mmmah] is given and it has low frequency when punctuation [kasrah] is given. Consonant [m] has a high frequency when punctuation [kasrah] is given, and it has low frequency when punctuation $[$ fathah] is given. The
Table 6. Tone frequency of bilabial sounds

\begin{tabular}{|c|c|c|c|c|}
\hline Consonant & $\begin{array}{c}\text { Frequency } \\
\text { (Hz) }\end{array}$ & d్rammah & fathah & kasrah \\
\hline \multirow{4}{*}{$+/ \mathrm{b}$} & BT & 312.0 & 290.0 & 320.7 \\
\cline { 2 - 5 } & FT & 295.8 & 250.9 & 188.7 \\
\cline { 2 - 5 } & HT & 343.8 & 300.3 & 328.4 \\
\cline { 2 - 5 } & LT & 236.3 & 192.7 & 188.7 \\
\hline \multirow{4}{*}{ / m } & BT & 309.2 & 292.4 & 291.0 \\
\cline { 2 - 5 } & FT & 215.6 & 199.2 & 226.6 \\
\cline { 2 - 5 } & HT & 327.0 & 317.8 & 370.1 \\
\cline { 2 - 5 } & LT & 212.1 & 199.2 & 195.6 \\
\hline
\end{tabular}

Table 7. Tone frequency of labiodental sounds

\begin{tabular}{|c|c|c|c|c|}
\hline Consonant & $\begin{array}{c}\text { Frequency } \\
\text { (Hz) }\end{array}$ & d'ammah & fathah & kasrah \\
\hline \multirow{4}{*}{ if } & BT & 352.5 & 316.9 & 368.7 \\
\cline { 2 - 5 } & FT & 181.7 & 316.9 & 254.3 \\
\cline { 2 - 5 } & HT & 357.7 & 317.4 & 374.9 \\
\cline { 2 - 5 } & LT & 181.7 & 176.6 & 191.7 \\
\hline
\end{tabular}

order of bilabial sound frequencies from the highest to the lowest is [r] then [ب]. The table below shows the tone frequency of labiodental sounds.

Consonant [f] has a high tone when punctuation [kasrah] is given, this happens because of consonant [f] has a high wave vibration when it was articulated with punctuation [kasrah]. Moreover, this consonant has low tone when punctuation [d g $\left.^{\varsigma} a m m a h\right]$ is given. The table below shows the tone frequency of alveolar sounds.

The following table 8 shows the consonant of group alveolar sounds. Consonant $[ð]$ has a high tone frequency when punctuation [kasrah] is given. This condition happens because consonant [ð] when it experiences high vocal vibrations when it is followed by punctuation [kasrah]. But when this consonant is

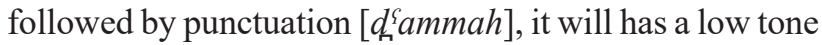
frequency. The consonant $[\theta]$ has a high tone frequency when it is followed by punctuation [fathah], and has a low tone frequency when it is followed by punctuation [kasrah]. The consonan [z] has a high frequency when it is followed by punctuation [fathah], and it has a low tone frequency when it is followed by [d ammah]. The order of alveolar sound frequencies from the highest to the lowest is $[\theta],[z],[ð]$. The table below shows the tone frequency of dental sounds. 
Table 8. Tone frequency of alveolar sounds

\begin{tabular}{|c|c|c|c|c|}
\hline Consonant & $\begin{array}{c}\text { Frequency } \\
(\mathrm{Hz})\end{array}$ & $d_{n}^{\varsigma} a m m a h$ & fathah & kasrah \\
\hline \multirow{4}{*}{ ذ / ð } & BT & 285.6 & 302.0 & 285.7 \\
\hline & FT & 190.0 & 287.4 & 265.1 \\
\hline & HT & 320.3 & 324.2 & 368.7 \\
\hline & LT & 190.0 & 209.3 & 210.0 \\
\hline \multirow{4}{*}{$ث$} & BT & 335.0 & 356.0 & 353.5 \\
\hline & FT & 335.0 & 249.4 & 222.9 \\
\hline & HT & 445.2 & 381.4 & 354.8 \\
\hline & $\mathrm{LT}$ & 103.4 & 249.4 & 206.0 \\
\hline \multirow{4}{*}{ ظ / } & BT & 283.4 & 268.0 & 274.8 \\
\hline & $\mathrm{FT}$ & 201.3 & 190.9 & 184.6 \\
\hline & HT & 304.3 & 363.2 & 361.7 \\
\hline & LT & 199.4 & 188.8 & 184.6 \\
\hline
\end{tabular}

The table 9 shows the group of dental sounds. Consonant [d] has a high tone frequency when it is followed by [kasrah] and has low tone frequency when it is followed by [fathah]. Consonant [d $\left.\mathrm{d}_{\mathrm{n}}^{\mathrm{i}}\right]$ has a high tone frequency when it is followed by [kasrah] and has low tone frequency when it is followed by [fathah]. Consonant [ $\mathrm{t}$ ] has a high frequency when it is followed by punctuation $\left[d_{n}^{\text {Sammah }}\right]$ and has a low tone frequency when it is followed by [fathah]. Consonant $\left[\mathrm{t}^{\mathrm{C}}\right]$ has a high tone frequency when it is followed by punctuation [fathah] and has a low tone frequency when it is followed by punctuation $\left[d_{n}^{\text {cammah }}\right.$. Consonant [s] has a high tone frequency when it is followed by punctuation [d $d_{n}^{\text {s }}$ ammah] and has a low tone frequency when it is followed by punctuation [fathah]. Consonant [z] has a high tone frequency when it is followed by punctuation [kasrah] and has a low tone frequency when followed by punctuation [fathah]. Consonant $\left[\mathrm{s}^{\zeta}\right]$ has a high tone frequency when followed by punctuation [ $\left.d_{n}^{\varsigma} a m m a h\right]$ and has a low tone frequency when followed by [kasrah]. The order of dental sound frequencies from the highest to the lowest is [t], $\left[\mathrm{t}^{\mathrm{S}}\right],[\mathrm{z}],[\mathrm{s}],[\mathrm{d}],\left[\mathrm{d}_{n}^{\uparrow}\right],\left[\mathrm{s}^{\mathrm{S}}\right]$. The table below shows the tone frequency of apico-alveolar sounds.

Based on table 10, the group of apico-alveolar sounds consists of consonant [1], [r], [n]. Consonant [1] has a high tone frequency when it is followed by punctuation [kasrah] and has a low tone frequency when followed by [fathah]. Consonant [r] has a high tone frequency when it is followed by punctuation [kasrah] and it has a low tone frequency when it is followed by punctuation [ $\left.\mathrm{d}_{\mathrm{n}}^{\mathrm{S}} \mathrm{ammah}\right]$. Consonant $[\mathrm{n}]$ has a high frequency when it is followed by
Table 9. Tone frequency of dental sounds

\begin{tabular}{|c|c|c|c|c|}
\hline Consonant & $\begin{array}{c}\text { Frequency } \\
(\mathrm{Hz})\end{array}$ & $d_{n}^{S} a m m a h$ & fathah & kasrah \\
\hline \multirow{4}{*}{$د / d$} & BT & 320.1 & 299.3 & 320.7 \\
\hline & FT & 235.0 & 262.8 & 218.8 \\
\hline & HT & 320.1 & 325.8 & 352.7 \\
\hline & LT & 220.1 & 174.2 & 204.1 \\
\hline \multirow{4}{*}{ 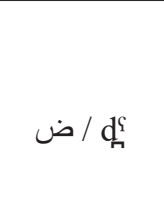 } & BT & 272.9 & 288.0 & 277.7 \\
\hline & FT & 172.4 & 210.7 & 240.5 \\
\hline & HT & 349.7 & 298.5 & 321.6 \\
\hline & LT & 172.4 & 163.2 & 139.9 \\
\hline \multirow{4}{*}{$ت / \mathrm{t}$} & BT & 408.1 & 353.5 & 296.4 \\
\hline & FT & 297.1 & 201.3 & 350.7 \\
\hline & HT & 408.1 & 361.8 & 350.7 \\
\hline & LT & 290.0 & 201.3 & 200.1 \\
\hline \multirow{4}{*}{$b / t^{\varsigma}$} & $\mathrm{BT}$ & 325.8 & 316.7 & 317.5 \\
\hline & FT & 267.0 & 377.8 & 229.9 \\
\hline & HT & 267.0 & 380.1 & 341.6 \\
\hline & LT & 212.9 & 175.1 & 215.3 \\
\hline \multirow{4}{*}{ / / / } & $\mathrm{BT}$ & 339.6 & 358.6 & 350.1 \\
\hline & FT & 325.1 & 179.2 & 193.6 \\
\hline & HT & 339.6 & 358.6 & 350.1 \\
\hline & LT & 208.2 & 162.1 & 193.6 \\
\hline \multirow{4}{*}{$j / z$} & BT & 278.4 & 303.5 & 285.4 \\
\hline & FT & 207.4 & 160.7 & 270.9 \\
\hline & HT & 342.1 & 318.4 & 320.5 \\
\hline & LT & 207.4 & 160.7 & 239.3 \\
\hline \multirow{4}{*}{ S / ص } & BT & 346.4 & 322.2 & 351.7 \\
\hline & FT & 194.1 & 194.0 & 85.6 \\
\hline & HT & 346.4 & 322.2 & 359.2 \\
\hline & LT & 194.1 & 130.3 & 85.6 \\
\hline
\end{tabular}

punctuation $\left[d_{n}^{\text {S}} a m m a h\right]$ and has a low frequency when it is followed by punctuation [fathah]. The order of apicoalveolar sound frequencies from the highest to the lowest is [1], [r], [n]. The table below shows the tone frequency of apico palatal sounds.

Based on table 11, the group of apico-palatal sounds consists of consonant [J] and [j]. Consonant [J] has a high tone frequency when it is followed by punctuation $\left[d_{n}^{\varsigma} a m m a h\right]$ and this consonant has a low tone frequency when it is followed by punctuation [fathah]. Consonant [j] has a high tone frequency when it is followed by 
Table 10. Tone frequency of apico-alveolar sounds

\begin{tabular}{|c|c|c|c|c|}
\hline Consonant & $\begin{array}{c}\text { Frequency } \\
(\mathrm{Hz})\end{array}$ & $d_{n}^{\varsigma} a m m a h$ & fathah & kasrah \\
\hline \multirow{4}{*}{1 /J } & BT & 304.6 & 289.4 & 364.2 \\
\hline & FT & 207.7 & 193.1 & 194.8 \\
\hline & HT & 399.4 & 308.3 & 359.6 \\
\hline & LT & 194.9 & 193.1 & 194.8 \\
\hline \multirow{4}{*}{$\mathrm{J} / \mathrm{r}$} & BT & 303.2 & 302.3 & 275.3 \\
\hline & FT & 174.2 & 225.9 & 227.4 \\
\hline & HT & 324.1 & 335.2 & 352.7 \\
\hline & LT & 174.2 & 196.9 & 213.5 \\
\hline \multirow{4}{*}{ / / } & $\mathrm{BT}$ & 309.3 & 319.9 & 319.1 \\
\hline & FT & 233.5 & 114.1 & 228.5 \\
\hline & HT & 337.1 & 319.9 & 362.5 \\
\hline & LT & 206.4 & 106.6 & 165.8 \\
\hline
\end{tabular}

Table 11. Tone frequency of apico-palatal sounds

\begin{tabular}{|c|c|c|c|c|}
\hline Consonant & $\begin{array}{l}\text { Frequency } \\
(\mathrm{Hz})\end{array}$ & $d_{n}^{\complement} a m m a h$ & fathah & Kasrah \\
\hline \multirow{4}{*}{ ك / / } & $\mathrm{BT}$ & 376.2 & 320.4 & 332.2 \\
\hline & FT & 210.9 & 208.2 & 244.3 \\
\hline & HT & 397.8 & 326.1 & 338.0 \\
\hline & LT & 210.9 & 196.5 & 201.8 \\
\hline \multirow{4}{*}{ ج/j / ج } & BT & 350.7 & 328.3 & 298.6 \\
\hline & FT & 236.7 & 254.4 & 234.2 \\
\hline & HT & 354.0 & 328.3 & 304.7 \\
\hline & LT & 216.3 & 208.8 & 214.6 \\
\hline
\end{tabular}

punctuation $[f a t \hbar a h]$ and it has a low tone frequency when it is followed by punctuation [kasrah]. The order of apicoplatal sound frequencies from the highest to the lowest is [J], [j]. The table below shows the tone frequency of uvular sounds.

Based on table 12 the group of uvular sounds consist of consonant [k] and [q]. Consonant [k] has a high tone frequency when followed by punctuation $\left[d_{n}^{\varsigma} a m m a h\right]$ and it has a low frequency when followed by punctuation [fathah]. Consonant [q] has a high tone frequency when followed by punctuation [kasrah] and it has a low tone frequency when followed by punctuation [fathah]. The order of uvular sound frequencies from the highest to the lowest is $[\mathrm{k}],[\mathrm{q}]$. The table below shows the tone frequency of pharyngeal sounds.

The table above shows the group of pharyngeal
Table 12. Tone frequency of uvular sounds

\begin{tabular}{|c|c|c|c|c|}
\hline Consonant & $\begin{array}{c}\text { Frequency } \\
(\mathrm{Hz})\end{array}$ & d'ammah & fathah & kasrah \\
\hline \multirow{3}{*}{$5 / \mathrm{k}$} & $\mathrm{BT}$ & 364.5 & 300.6 & 314.0 \\
\cline { 2 - 5 } & $\mathrm{FT}$ & 199.5 & 207.5 & 186.7 \\
\cline { 2 - 5 } & $\mathrm{HT}$ & 388.4 & 309.0 & 361.8 \\
\cline { 2 - 5 } & $\mathrm{LT}$ & 194.4 & 207.5 & 186.7 \\
\hline \multirow{3}{*}{$* / \mathrm{q}$} & $\mathrm{BT}$ & 329.8 & 312.8 & 350.3 \\
\cline { 2 - 5 } & FT & 88.4 & 98.3 & 243.9 \\
\cline { 2 - 5 } & HT & 362.4 & 316.5 & 354.8 \\
\cline { 2 - 5 } & LT & 88.4 & 98.3 & 221.6 \\
\hline
\end{tabular}

Table 13. Tone frequency of pharyngeal sounds

\begin{tabular}{|c|c|c|c|c|}
\hline Consonant & $\begin{array}{c}\text { Frequency } \\
(\mathrm{Hz})\end{array}$ & d'ammah & fathah & kasrah \\
\hline \multirow{4}{*}{$\dot{\varepsilon} / \gamma$} & BT & 273.6 & 341.3 & 287.9 \\
\hline & FT & 221.6 & 167.3 & 282.0 \\
\hline & HT & 282.5 & 346.9 & 329.4 \\
\hline & LT & 103.5 & 167.3 & 227.7 \\
\hline \multirow{4}{*}{$\dot{\tau} / x$} & $\mathrm{BT}$ & 339.9 & 321.3 & 340.1 \\
\hline & FT & 256.4 & 271.0 & 270.8 \\
\hline & HT & 343.7 & 321.3 & 348.0 \\
\hline & $\mathrm{LT}$ & 162.5 & 210.3 & 200.9 \\
\hline \multirow{4}{*}{$\varepsilon / \mathrm{s}$} & BT & 330.9 & 279.6 & 289.9 \\
\hline & FT & 189.6 & 204.3 & 236.8 \\
\hline & HT & 325.8 & 350.0 & 323.6 \\
\hline & LT & 176.2 & 204.3 & 178.4 \\
\hline \multirow{4}{*}{$\tau^{/ \hbar}$} & $\mathrm{BT}$ & 364.0 & 334.1 & 325.7 \\
\hline & FT & 174.2 & 186.1 & 293.0 \\
\hline & HT & 386.7 & 334.1 & 326.9 \\
\hline & LT & 174.2 & 186.1 & 289.0 \\
\hline \multirow{4}{*}{$\circ / \mathrm{h}$} & BT & 284.1 & 270.5 & 299.0 \\
\hline & FT & 214.0 & 226.4 & 221.1 \\
\hline & $\mathrm{HT}$ & 323.8 & 315.2 & 305.3 \\
\hline & LT & 213.7 & 209.9 & 208.6 \\
\hline
\end{tabular}

sounds that consists of $[\gamma],[\mathrm{x}],[\mathrm{C}],[\hbar],[\mathrm{h}]$. All sounds can be pronounced if a punctuation [ d a $a m m a h]$ is given, $[$ fathah], and $[$ kasrah $]$. The consonant $[\gamma]$ has a high tone frequency when it is followed by punctuation [kasrah] and it has a low tone frequency when it is followed by punctuation $\left[d_{n}^{\text {s }} a m m a h\right]$. The consonant $[\mathrm{x}]$ has a high 
tone frequency when it is followed by punctuation [kasrah], and this consonant has a low tone frequency when it is followed by punctuation [d $\left.{ }_{n}^{\varsigma} a m m a h\right]$. The sound of consonant [C] has a high tone frequency when it is followed by punctuation [fathah] and this consonant has a low tone frequency when followed by punctuation [d ${ }^{\text {f }}$ ammah]. The sound of consonant [ $\hbar$ ] has a high tone frequency when followed by punctuation [kasrah] and it has a low tone frequency when followed by punctuation [fathah]. The sound of consonant [h] has a high tone frequency when followed by punctuation [ $\left.d_{n}^{\varsigma} a m m a h\right]$ and has a low frequency when it is followed by punctuation [fathah]. The order of pharyngeal sound frequencies from the highest to the lowest is $[\hbar],[\mathrm{C}],[\mathrm{x}],[\mathrm{h}],[\gamma]$.

\section{CONCLUSION}

The result of the analysis showed that the fundamental frequency is correlated with the tone. If the fundamental frequency was high, so did the tone. A vowel sound with the high fundamental frequency is the sound $[\mathrm{u}]$ followed by [i], then [a]. The high and low frequency of vowel sounds affected the frequency of the consonant sound followed by the vowel. It was known that 52\% of consonants with the high tone were accompanied by punctuation [ $\left.d_{n}^{\varsigma} a m m a h\right], 40 \%$ accompanied by punctuation [kasrah] and 8\% accompanied by punctuation [fathah]. The highest frequency sounding group was the apicopalatal sound. It happened since the apico-palatal sound was produced by vocal cord in a high vibration influencing the fundamental frequency and tone. Whereas, the group of consonant sounds with the lowest frequency was a pharyngeal sound as it had a low vibration on the vocal cord; hence, it only produced the low frequency sound.

\section{REFERENCES}

Almisreb, A. A., Ahmad, F.A., Nooritawati, Md. T. (2015). An Acoustic Investigation of Arabic Vowels Pronounced by Malay Speaker. Journal of King Saud University, 28(2), 148-156. Accessed $4^{\text {th }}$ of June 2017. Retrieved from http://www.sciencedirect.com/-science/article/ pii-/S1319157815000907.

Alqattan, Shaima (2015). Early Phonological Acquisition by Kuwaiti Arabic Children. Dissertation. School of Education Communication and Language Sciences, Newcastle University. Accessed $5^{\text {th }}$ of May 2017. Retrieved from https://theses.ncl.ac.uk/dspace/ bitstream/10443/2787/1/-Alqattan \%2C\%20S.\%20 15.pdf.

Anis, Ibrahim (1999). Al-Ashwaat Al-Lhughawiyyah. Egypt: Maktabah Anglo.
Hartanti, J. Erwin. Riad, S. (2016). Analisa Karakteristik Spektrum Suara Anak Paud Menggunakan Software Praat. Repository University of Riau. Accessed 23 $3^{\text {rd }}$ August 2017. Retrieved from http://repository-. unri.ac.id/xmlui/bitstream/handle/123456789/7879/ KI\%20revisi\%2018\%20agustus\%20FIX. pdf?sequence $=1$.

Irawan, Yusup (2012). Kontras Intonasi DeklaratifInterogatif dalam Bahasa Sunda. Thesis. Indonesia University. Accessed $4^{\text {th }}$ of June 2017. Retrieved from from lib.ui.ac.id.

Irawan, Yusup (2017). Fonetik Akustik. Bandung: Angkasa. Kadir, N.A.A. \& R. Sudirman (2011). Difficulties of Standard Arabic Phonemes Spoken by Non-Arab Primary School Children Based on Formant Frequencies. Journal of Computer Science, 7(7), 1003-1010. Accessed $14^{\text {th }}$ of May 2017. Retrieved from http:// thescipub.com-/PDF/jcssp.2011.-1003.1010.pdf.

Al-Khuli, M. A. (1991). A Dictionary of Theoretical Linguistics. Beirut: Librairie du Liban.

Kridalaksana, H. (2009). Kamus Linguistik Edisi Keempat. Jakarta: Gramedia.

Ito, K. \& Pauline, W. (2002). Praat Tutorial. Ohio: Amerika Serikat. Accessed $4^{\text {th }}$ of June 2017. Retrieved from http://thescipub.com/PDF/jcssp.2011.-1003.1010. pdf.

Subali, Muhammad. Miftah, Andriansyah. Christanto, S. (2015). Analisis Frekuensi Dasar dan Frekuensi Formant dari Fonem Huruf Hijaiyah untuk Pengucapan Makhraj dengan Metode DTW. Ejournal Gunadarma, 6, 60-73. Accessed 14 ${ }^{\text {th }}$ of May 2017. Retrieved from https://ejournal.gunadarma.ac.id/ index.php/pesat/article/view/1370.

Sangidu (1991). Bunyi-Bunyi Segmental dan Suprasegmental Bahasa Arab (Tinjauan Fonologis dan Grafemis). Research Report. Faculty of Literature, Gajah Mada University.

Sudaryanto (2015). Metode dan Aneka Teknik Analisis Bahasa. Yogyakarta: Sanata Darma University Press. 